\title{
Characterization and evaluation of the antimicrobial properties of algal alginate; a potential natural protective for cosmetics
}

\author{
Selin SAYIN 1 * D , Tolga DEPCI 2 (D), Mehmet NAZ 3 (D), Selda SEZER 4 (D), \\ Merve Gökşin KARAASLAN ${ }^{5}$ (D) , Aycan ARAS ${ }^{1}$ (D), Sinem UĞUR ${ }^{1}$ (D), Zafer ÇETIN 6 (D), \\ Eyüp İlker SAYGILI 7 (D), Burhan ATEŞ ${ }^{4}$ (D)
}

1 Department of Marine Technologies, Faculty of Marine Sciences and Technology, Iskenderun Technical University, 31200 Hatay, Turkey.

2 Department of Petroleum and Natural Gas Engineering, Faculty of Engineering and Natural Sciences, Iskenderun Technical University, 31200 Hatay, Turkey.

3 Department of Aquaculture, Faculty of Marine Sciences and Technology, Iskenderun Technical University, 31200 Hatay, Turkey.

4 Department of Chemistry, Faculty of Arts and Science, Inonu University, 44280 Malatya, Turkey.

5 Department of Property Protection and Security, Taşkent Vocational High School, Selcuk University, 42960 Konya, Turkey.

6 Department of Medical Biology, Faculty of Medicine, SANKO University, 27090 Gaziantep, Turkey.

7 Department of Biochemistry, Faculty of Medicine, SANKO University, 27090 Gaziantep, Turkey.

* Corresponding Author. E-mail: selin.sayin@iste.edu.tr (S.S.); Tel. + Tel: +90326 6135600.

Received: 27 January 2021 / Revised: 27 October 2021 / Accepted: 18 November 2021

\begin{abstract}
Sargassum vulgare was sampled by free dives in Iskenderun Bay, Hatay, Turkey, in September 2018. Sargassum vulgare is a material with high economic value because it has compounds that can be used in medical applications such as alginic acid and at the same time it contains carbohydrates and vitamins. Alginates were extracted with a sequential extraction protocol from Sargassum vulgare. Structural characterization of alginate obtained from Sargassum vulgare was determined by FT-IR spectrum, phase structure by XRD diffractometer, and surface morphology by SEM image. Within the scope of the study, alginate obtained from Sargassum vulgare and herbal preservative 705 used in the field of cosmetics were compared. After pretreatment of Sargassum vulgare with ethanol, alginate extraction was performed. Microorganisms of Pseudomonas aeruginosa, Staphylococcus aureus, Candida albicans, Escherichia coli, Aspergillus brasiliensis were used to examine the antimicrobial activity of the obtained alginate and showed that the contamination risk was tolerable for all microorganisms examined on the seventh day of incubation. Alginate obtained from Sargassum vulgare was found to be more effective than herbal preservative 705 at 0 hours. Pseudomonas aeruginosa, Staphylococcus aureus are microorganisms with the highest effect in the 0 hour. Since alginate obtained from Sargassum vulgare is more effective on microorganisms in a shorter time than herbal preservative 705, it is predicted that it can be a product that can be used in the field of cosmetics.
\end{abstract}

KEYWORDS: Sargassum vulgare; algae; antimicrobial activity; alginates; natural cosmetics.

\section{INTRODUCTION}

Algae are plants with a simple photosynthetic and unicellular reproductive structure [1]. In marine ecosystems, macroalgae are potential primary producers of energy-rich compounds and are cited as sources of biologically active metabolites $[2,3]$. Marine macroalgae are rich sources of bioactive compounds as they can produce various secondary metabolites such as phenols, flavonoids, glycosides, and sterols with important biological roles such as antifungal and anti-diabetic effects. In addition, they have antiinflammatory, antimalarial, antioxidant, antiviral, and antibacterial activities [4]. Recently, there has been an increasing number of studies on the use of secondary metabolites from natural sources, including seaweeds, to treat antibiotic-resistant bacteria, become a worldwide problem in health and medicine, and to replace safer antibiotic use [5-7].

How to cite this article: Sayın S, Depci T, Naz M, Sezer S, Karaaslan MG, Aras A, Uğur S, Çetin Z, Saygllı I, Ateş B. Characterization and evaluation of the antimicrobial properties of algal alginate; a potential natural protective for cosmetics. J Res Pharm. 2022; 26(1): 198-209. 
Sargassum spp. like brown seaweeds have been reported to have bioactive properties against a number of medically important Gram-negative and Gram-positive bacteria, such as Escherichia coli, Pseudomonas aeruginosa, Klebsiella pneumoniae, Clostridium perfringens, Staphylococcus aureus [8-10]. For this reason, Sargassum has been known as a candidate sustainable natural reserve resource with hopeful antibacterial biological activities connect with its primary and secondary metabolites [11]. Sargassum spp. is a brown (Phaeophyceae) macroalgae genus in the order of Fucales, which usually live in shallow and temperate waters, represented by a large number of species. It is a species with high economic value due to high carbohydrate, protein, vitamin, mineral, and fiber content [12]. Sargassum also contains phycocolloids and bioactive compounds such as alginic acid and fucoid and polyphenols that could potentially be used in nutraceutical and medical applications [13]. According to the researches, Sargassum species have antioxidant (DPPH radical scavenging) [14,15]; cholinesterase inhibitory [16]; neuroprotective [17]; anti-cancer [18] and antiviral (HSV-1) [19] properties. It has been also reported that they have a protective effect against diabetes and obesity [20]. Alginate obtained from Laminaria Digitata, Laminaria japonica, Ascophyllum nodosum, and Macrocystis pyrifera [21] species of brown algae (Phaeophyceae) is a highly abundant polysaccharide in nature with aqueous alkaline solutions, typically $\mathrm{NaOH}[22]$.

Since Sargassum vulgare has alginic acid and fucoidan components, it is safer to use than other types of algae [23]. It can be used as an antioxidant hair care agent as a skin care agent and as a thickener because it can gel, it is non-toxic and can be used in the form of alginic acid [24].

Industrial applications of alginates are found mainly in the food, medical, pharmaceutical, and textile industries and are linked to their ability to hold water as well as gelling, viscosity, and stabilizing [25]. Biotechnological applications are based on instantaneous and almost temperature-independent physical crosslinking and sol/gel transition in the presence of multivalent cations (e.g., $\mathrm{Ca}^{2+}$ ) in an aqueous medium [25]. The unique properties of alginate make it a potential biopolymer that can overcome the problems of currently used wound dressings by increasing the absorption of wound exudates and minimizing bacterial infections, reducing adverse allergic effects, and improving wound healing due to its biocompatibility. It also exhibits hemostatic properties that are beneficial for bleeding wounds [26]. Alginates are widely used in the cosmetics industry due to their properties such as emulsifier, thickener, and dehumidifier [48]. They are like hyaluronic acid in skincare products as they do not dissolve in water and swell and retain water [49]. It is also used in many products such as hand creams and lotions, creams, pomades, non-oily creams, toothpaste. In addition, alginates as antioxidative agents help prevent skin aging and disorders. Due to their antioxidant properties, they can also be used as preservatives in cosmetic products by preventing lipid oxidation [50,51].

Alginates are unbranched polysaccharides composed of $\beta-1,4$ linked D-mannuronic acid (M) and its C5 epimer $\alpha$-L-guluronic acid $(\mathrm{G})$. The natural copolymer is an essential component of algae and is also an exopolysaccharide of bacteria including Pseudomonas aeruginosa. It consists of M (M block) and G (G block) residue sequences interspersed with MG sequences (MG-blocks). Although it is possible to obtain alginates from both algae and bacterial sources, commercially available alginates currently only obtained from algae [27]. Calcium crosslinked alginate hydrogels have been used in drug delivery and cell transplant applications in recent years. In addition, alginate hydrogels have been extensively studied for cartilage and bone regeneration applications as scaffold components $[28,29]$. The first report on the chemical structure of alginates was published as early as 1966. Larsen et al. [30] described in detail the fractionation following partial hydrolysis of alginates to obtain alginates containing different copolymer compositions. Fractionation gave soluble (hydrolyzable) and insoluble (resistant) fractions. Resistant fractions consisted of molecules that were either mainly M-rich or G-rich residues, while hydrolyzable fractions consisted of highly varying MG residues. Therefore, a structure consisting of M blocks, G blocks, and hydrolyzable MG alternative blocks was proposed [31].

Today, many different compounds can be used as additives in cosmetic products in order to prevent microbial contamination, to extend their shelf life, and to protect the health of users. Some examples of these compounds contain; alcohol, aluminum chlorohydrate, aluminum salts, triclosan, 3,4,40-trichlorocarbanilide, chlorhexidine, zirconium-aluminum tetrachlorohydrex glycine complex in deodorants and antiperspirants; coal, imidazole derivatives, glycolic acid, salicylic acid, steroids, tar and sulfur derivatives, piroctone olamine, zinc pyrithione in rinse-off hair products; alcohol, benzalkonium chloride, glycerin, natural ingredients, triclocarban, triclosan and in skincare products; benzalkonium chloride in face care products; triclosan, chlorhexidine and natural extracts in toothpaste; microban ${ }^{\circledR}$ and triclosan in antibacterial tooth brushed; trichlosan and chlorhexidine in mouthwashes [32]. It has been determined that molecules such as imidazolimidyl urea, diazolidinyl urea, formaldehyde, paraformaldehyde, benzalkonium chloride, parabens, methylchloroisothiazolinone, methylisothiazolinone, methyl dibromo glutaronitrile, and phenoxyethanol, 
which are used as preservatives in cosmetic products, may cause allergic reactions in humans and cause side effects related to different tissues and organs [33]. Therefore, in order to reduce the concentrations of antimicrobial synthetic molecules used in cosmetic products, natural preservative boosters of plant origin and also have antimicrobial properties and their mixtures with low doses of synthetic antimicrobial molecules have come to the fore [34]. As a result of many studies conducted in recent years, it has been shown that ethanol extracts, methanol extracts of aqueous extracts obtained from some algae species, and some algal compounds including sesquiterpenes, phenolic ingredients, laurenterols, bromophenols, fatty acids, and sulfated polysaccharides also have antimicrobial activity, and it is thought that these natural compounds can be used for preservative purposes in cosmetic products [35]. As a natural raw material in the cosmetics industry, seaweed is a source for sustainable inexpensive innovative personal care products that can meet consumer needs and expectations [36]. There are studies on different cosmetic formulations such as the components obtained from algae to prevent skin aging [37,38]. In addition, the bioactive properties of Sargassum vulgare offer potential use in cosmetics [39].

Alginate obtained from Sargassum vulgare was compared with the natural, bioactive preservative glyceryl caprylate and glyceryl undecylenate used as a commercial product. glyceryl caprylate and glyceryl undecylenate is a multifunctional ingredient system applied for cosmetics.

In this study, it was aimed to examine the antimicrobial properties of alginate obtained from Sargassum vulgare and compared with the commercially used herbal 705 preservative containing glyceryl caprylate and glyceryl undecylenate with antimicrobial properties. As a result of the analyzes made, it was observed that the alginate obtained from Sargassum vulgare was more effective on microorganisms in a shorter time than the herbal preservative 705. Thus, it was predicted that the alginate obtained from Sargassum vulgare could be used as an alternative product in the field of cosmetics and studies on this subject are continuing.

\section{RESULTS AND DISCUSSION}

\subsection{Characterization of alginates extracted from Sargassum spp.}

Structural characterization of alginates extracted from Sargassum spp. was determined by XRD and FTIR spectrum, and surface morphology was also determined by SEM image.

The XRD analysis revealed important information about the alginate crystal. It was seen that the peaks shown in Figure 1 were due to the characteristic peaks of sodium alginate and calcium alginate. The peaks observed in the range of $16.86^{\circ}$ to $32.26^{\circ}, 40.24^{\circ}, 45.10^{\circ}$, respectively. Bharatham et al. (2014) stated that it corresponds to the characteristic peaks arising from cross-linked calcium and sodium alginate structures. [40].

The FT-IR spectrum of the alginate extracted from Sargassum vulgare and pure alginate was shown in the Figure 2. O-H tensile vibrations of alginate were observed at 3000-3600 $\mathrm{cm}^{-1}$ and aliphatic C-H stretching vibrations at $2900 \mathrm{~cm}^{-1}$. The bands that come in the range of $1600-1400 \mathrm{~cm}^{-1}$ were caused by the symmetrical and asymmetrical vibrations of the carboxylate salt ions. COO-stretching peaks formed as a result of the treatment with calcium and sodium were seen at 1600-1620 $\mathrm{cm}^{-1}$. According to the study of Fenoradosoa et al., it is seen that the alginate structure obtained from Sargassum turbinarioides has a similar structure of -OH and $\mathrm{COO}^{-}$peaks in the alginate structure obtained from the synthesized Sargassum spp. [41]. As a result, it was seen that COO- peaks were changed by electrostatic interaction in sodium and calcium alginate (Figure 2). When the FT-IR spectrum of pure alginate and alginate extracted from Sargassum vulgare was compared, it was seen that alginate extraction has taken place. These results confirmed that alginate extraction was successfully carried out.

SEM images of alginates obtained from Sargassum vulgare and pure alginate at $10 \mu \mathrm{m}$ and $20 \mu \mathrm{m}$ magnifications are shown in Figure 3. Morphological changes were observed on powder surfaces as a result of the uneven precipitation of alginates. At $10 \mu \mathrm{m}$ SEM images, the morphologies originating from the crosslinked structure in the pure alginate structure are similar. At $20 \mu \mathrm{m}$ images, the presence of dispersed structures is confirmed. Therefore, SEM images of pure alginate and alginates synthesized from Sargassum vulgare are compatible with each other.

\subsection{Antimicrobial activity of alginates extracted from Sargassum spp.}

Previously studies also indicated the ethanol extract had a stronger antibacterial or antimicrobial activity [42,43]. Kolanjinathan et al. [44] investigated ethanol extracts that were obtained from 3 different 
macroalgae against a total of 6 pathogenic bacteria. Researchers indicated that ethanol extracts of Gracilaria edulis inhibited the growth of all investigated microorganisms except Bacillus cereus and Enterobacter aerogenes. Gerasimenko et al. [45] evaluated the ethanol extract of Laminaria cichorioideae brown algae and indicated that the extract had an antimicrobial effect on all microorganisms evaluated. Seenivasan et al. [46] marked that $80 \%$ ethanol, methanol and acetone extracts of three green algae collected from the southeastern coasts of India have the ability to inhibit the growth of evaluated gram-negative and gram-positive bacteria.

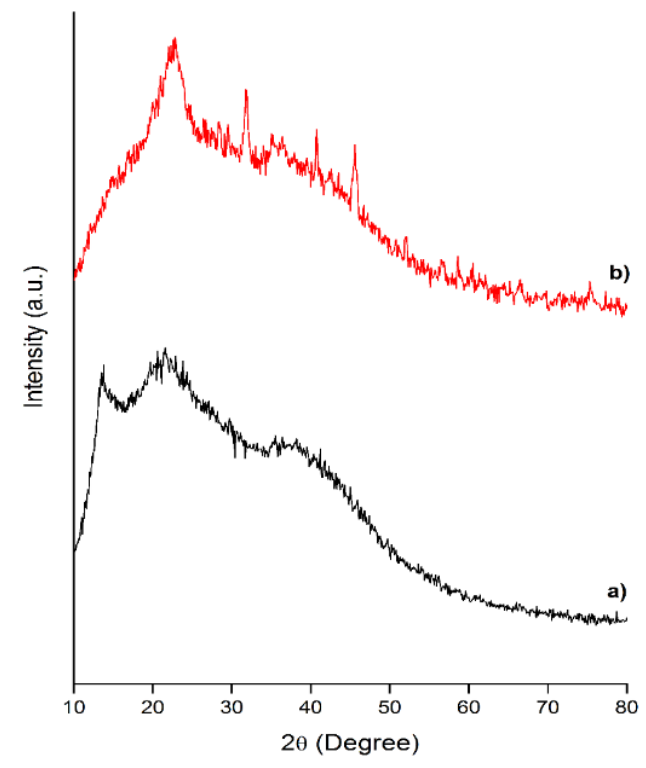

Figure 1. XRD spectrum of alginate extracted at $10-80^{\circ}$ (a) pure alginate, b) alginate obtained from Sargassum vulgare).

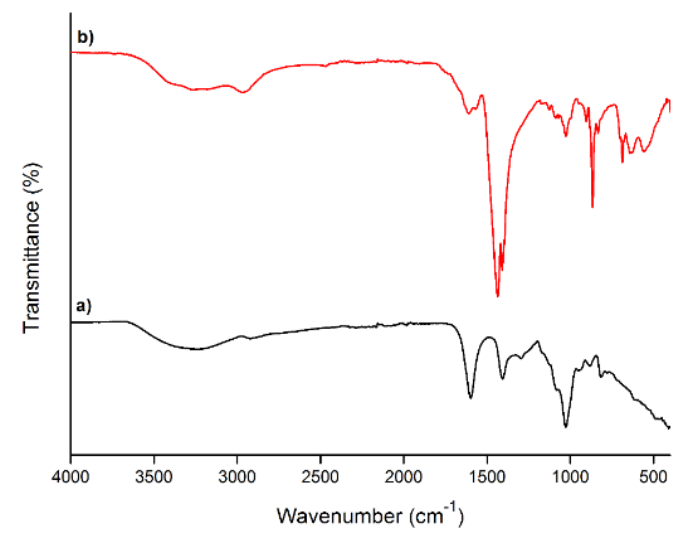

Figure 2. FT-IR spectra of alginate extracted and pure alginate at 400-4000 $\mathrm{cm}^{-1}$ (a) pure alginate, b) alginate obtained from Sargassum vulgare).

The microbial safety of products used in many areas for various purposes is an important issue. In this context, adding substances with a different chemical structure known as preservatives to the products is considered as one of the most important steps to ensure microbiological stability. These preservatives, which are used in a wide range, are especially desired to be compatible with the product they are added to, to be effective even at low concentrations against all kinds of microorganisms, to have no allergic, toxic or irritating effects on the organisms and to be stable at changing temperatures and $\mathrm{pH}$ values. In recent years, alginate produced from brown algae has a wide use as a preservative agent in terms of providing the desired properties. For this purpose, the effectiveness of the preservative substance used against microbial growth of the alginate structure that we extracted from Sargassum vulgare was tested. 

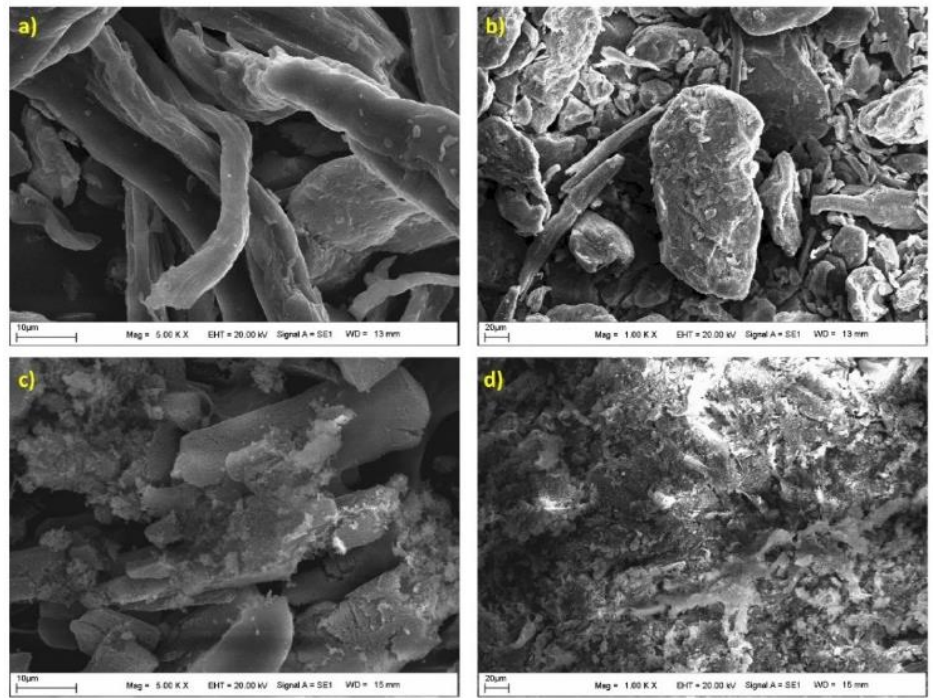

Figure 3. SEM images of extracted alginate and pure alginate (a) pure alginate $10 \mu \mathrm{m}, \mathrm{b}$ ) pure alginate 20 $\mu \mathrm{m}, \mathrm{c}$ ) alginate extracted from Sargassum vulgare $10 \mu \mathrm{m}, \mathrm{d}$ ) alginates obtained from Sargassum vulgare $20 \mu \mathrm{m}$ ).

The total aerophilic mesophilic microorganism and mold and yeast content of the product were determined using ISO 21149 and ISO 16212 standard methods, respectively. In these standard methods, the limit value of the number of microorganisms in the product is $<100 \mathrm{CFU} / \mathrm{g}$. As a result of the analysis, it was observed that the pure alginate and alginate extracted from Sargassum vulgare contained $<10 \mathrm{CFU} / \mathrm{g}$ microorganisms and this value was below the limit values, and it was determined that the pure alginate and alginate extracted from Sargassum vulgare did not have any microorganism load. The ISO 11930: 2012 standard is a system used to evaluate the antimicrobial protection of a cosmetic product. For Criterion A in the ISO 11930:2021 standard, the product is expected to show $\geq 3$ logarithmic reduction in bacteria and $\geq 1$ logarithmic reduction in yeasts. For criterion $B$, the product is expected to cause $\geq 0$ logarithmic reductions in mold. The antimicrobial preservative efficacy of the pure alginate and alginate extracted from Sargassum vulgare was evaluated by finding the difference between the logarithmic value of the number of bacteria culturing at the end of the incubation period and the initial logarithmic value of the microorganisms. The results obtained at the end of the 7th, 14th, and 28th days of the incubation periods of five different microorganism species including Staphylococcus aureus (ATCC 6538), Pseudomonas aeruginosa (ATCC 9027), Candida albicans (ATCC 10231) Aspergillus brasiliensis (ATCC 16404) Escherichia coli (ATCC 8739) ISO 11930:2012. It was determined that pure alginate caused a logarithmic decrease of $5.54 \mathrm{CFU} / \mathrm{g}$ for Staphylococcus aureus, $5.41 \mathrm{CFU} / \mathrm{g}$ for Pseudomonas aeruginosa, $5.56 \mathrm{CFU} / \mathrm{g}$ for Escherichia coli, $3.32 \mathrm{CFU} / \mathrm{g}$ for Candida albicans, and $3.30 \mathrm{CFU} / \mathrm{g}$ for Aspergillus brasiliensis on the test days. When the results were evaluated, it was seen that pure alginate met criterion A for bacteria and yeast and criterion B for molds. Therefore, the pure alginate was evaluated as antimicrobially effective.

With the ISO 11930: 2012 standard, the antimicrobial activity of the alginate extracted from Sargassum vulgare on Staphylococcus aureus (ATCC 6538), Pseudomonas aeruginosa (ATCC 9027), Escherichia coli (ATCC 8739) bacteria, Candida albicans (ATCC 10231) yeast and Aspergillus brasiliensis (ATCC 16404) mold is evaluated. In order to evaluate the product effectively, the log value of the decrease in the number of microorganisms at the end of 7, 14 and 28 days should be within the range given in the standard. Accepted log reduction values for bacteria 7,14 and 28 days $\geq 3 ; 7,14$ and 28 days $\geq 1$ for yeast; 14 th day for mold is $\geq 0$ and 28 th day is $\geq 1$. The product showed the desired logarithmic reduction in the standard on the 7th day on all microorganisms. The number of microorganisms on the 14 th and 28 th days was determined as $<10 \mathrm{CFU} / \mathrm{g}$. When these results were evaluated according to the antimicrobial preservative efficacy of the alginate structure obtained from Sargassum vulgare, it was determined that corresponded to the Criterion A level where the risk was tolerable for all microorganism species after the 7th day incubation period (Table 1). When compared with Sargassum vulgare herbal preservative 705 , it is seen to have antimicrobial activity like the herbal preservative used in cosmetics. As a result, it has been shown that the alginate material obtained from Sargassum vulgare can be used as a protective product. When all the results were evaluated, it was found that the product was protected against microbial growth (Figure 4). 


\section{CONCLUSION}

For a long time, many of the substances extracted from macroalgae have been used in herbal medicine, pharmacology, natural cosmetics, food, and other industrial areas due to their bioactive components such as alginates, carrageenan, and agar. Anti-bacterial, antiviral, anti-tumor, anti-inflammatory, and antifouling effects exist in other compounds. Seaweed may also provide promising bioactive that can be used to treat human diseases, and for new antimicrobial agents to be used in agriculture, and the food industry to replace synthetic antibacterial agents. However, the antimicrobial capacity of macroalgae extracts is related to different parameters such as macroalgae type, solvent, extraction method, and microorganism type. This antimicrobial effect will take apart among natural protective antimicrobial agents in different areas of the industry in further studies. Different studies have shown that marine algae can be a source of active compounds against pathogens. Cosmetic product: it defines all substances or mixtures that are prepared to be applied to the outer parts of the human body, whose sole or main purpose is to clean these parts, to smell them, to change their appearance, to protect them, to keep them in good condition or to correct body odors. Various natural or synthetic preservatives are used in cosmetic products. Preservatives are substances that aim to prevent microorganisms from developing in cosmetic products, either solely or mainly. Choosing the right preservative is an important issue in cosmetic formulations. It should be suitable for the $\mathrm{pH}$ of the product to be developed, resistant to production conditions, stable in the formulation of the product, suitable for the use of the product, the desired preservation period and the relevant regulations. Herein, natural component may be important molecules as a potential protective agent.

Table 1. Antimicrobial results of alginates extracted from Sargassum spp. and herbal protective 705.

\begin{tabular}{|c|c|c|c|c|c|c|c|}
\hline \multicolumn{8}{|c|}{ Antimicrobial results of alginates extracted from Sargassum spp. } \\
\hline \multirow{2}{*}{ Microorganism } & \multicolumn{2}{|c|}{ Hour 0} & \multicolumn{3}{|c|}{ 7th Day } & $\begin{array}{l}\text { 14th } \\
\text { Day }\end{array}$ & $\begin{array}{l}\text { 28th } \\
\text { Day }\end{array}$ \\
\hline & CFU/g & $\begin{array}{c}\log \\
\mathrm{CFU} / \mathrm{g}\end{array}$ & CFU/g & $\log$ CFU/g & $\begin{array}{l}\text { Log } \\
\text { reduction }\end{array}$ & CFU/g & CFU/g \\
\hline $\begin{array}{l}\text { Staphylococcus aureus } \\
\text { ATCC 6538/Lot } 3221505\end{array}$ & $2.55 \mathrm{E}+07$ & 7.41 & $3.00 \mathrm{E}+03$ & 3.5 & 3.93 & $<10$ & $<10$ \\
\hline $\begin{array}{l}\text { Pseudomonas aeruginosa } \\
\text { ATCC } 9027 / \text { Lot } 3270513\end{array}$ & $2.60 \mathrm{E}+07$ & 7.41 & $5.00 \mathrm{E}+03$ & 3.7 & 3.72 & $<10$ & $<10$ \\
\hline $\begin{array}{l}\text { Candida albicans } \\
\text { ATCC 10231/Lot } 8067507\end{array}$ & $2.50 \mathrm{E}+06$ & 6.40 & $1.00 \mathrm{E}+03$ & 3.0 & 3.40 & $<10$ & $<10$ \\
\hline $\begin{array}{l}\text { Aspergillus brasiliensis } \\
\text { ATCC 16404/Lot } 3175110\end{array}$ & $2.10 \mathrm{E}+05$ & 5.32 & $4.00 \mathrm{E}+02$ & 2.6 & 2.72 & $<10$ & $<10$ \\
\hline $\begin{array}{l}\text { Escherichia coli } \\
\text { ATCC } 8739 / \text { Lot } 4835151\end{array}$ & $2.42 \mathrm{E}+07$ & 7.38 & $4.00 \mathrm{E}+03$ & 3.6 & 3.78 & $<10$ & $<10$ \\
\hline \multicolumn{8}{|c|}{ Antimicrobial results of Herbal Protective 705} \\
\hline \multirow{2}{*}{ Microorganism } & \multicolumn{2}{|c|}{ Hour 0} & \multicolumn{3}{|c|}{ 7th Day } & $\begin{array}{l}\text { 14th } \\
\text { Day }\end{array}$ & $\begin{array}{l}\text { 28th } \\
\text { Day }\end{array}$ \\
\hline & CFU/g & $\begin{array}{c}\log \\
\mathrm{CFU} / \mathrm{g}\end{array}$ & CFU/g & $\log \mathrm{CFU} / \mathrm{g}$ & $\begin{array}{l}\text { Log } \\
\text { reduction }\end{array}$ & CFU/g & CFU/g \\
\hline $\begin{array}{l}\text { Staphylococcus aureus } \\
\text { ATCC 6538/Lot } 3221505\end{array}$ & $3.5 \mathrm{E}+08$ & 6.54 & $<10$ & 1 & 5.54 & $<10$ & $<10$ \\
\hline $\begin{array}{l}\text { Pseudomonas aeruginosa } \\
\text { ATCC 9027/Lot } 3270513\end{array}$ & $2.6 \mathrm{E}+08$ & 6.41 & $<10$ & 1 & 5.41 & $<10$ & $<10$ \\
\hline $\begin{array}{l}\text { Candida albicans } \\
\text { ATCC 10231/Lot } 8067507\end{array}$ & $2.1 \mathrm{E}+06$ & 4.32 & $<10$ & 1 & 3.32 & $<10$ & $<10$ \\
\hline $\begin{array}{l}\text { Aspergillus brasiliensis } \\
\text { ATCC } 16404 / \text { Lot } 3175110\end{array}$ & $2.0 \mathrm{E}+06$ & 4.30 & $\begin{array}{c}\text { Not } \\
\text { performed }\end{array}$ & $\begin{array}{c}\text { Not } \\
\text { performed }\end{array}$ & $\begin{array}{l}\text { Not } \\
\text { performed }\end{array}$ & $<10$ & $<10$ \\
\hline $\begin{array}{l}\text { Escherichia coli } \\
\text { ATCC 8739/Lot } 4835151\end{array}$ & $3.6 \mathrm{E}+08$ & 6.56 & $<10$ & 1 & 5.56 & $<10$ & $<10$ \\
\hline
\end{tabular}

The current study revealed the physical characteristics and the antimicrobial protective effects of alginate extracted from Sargassum vulgare (Phaeophyta) macroalgae. XRD, FT-IR and SEM analysis methods were used to characterize the extracted alginates. Pseudomonas aeruginosa, Staphylococcus aureus, Candida albicans, Escherichia coli, Aspergillus brasiliensis microorganisms were used to examine the antimicrobial activity of the obtained alginate and commercial preservative. The alginate extracted from Sargassum spp. showed high 
antimicrobial properties against Staphylococcus aureus, Pseudomonas aeruginosa, Candida albicans, Aspergillus brasiliensis, Escherichia coli microorganism species. According to the antimicrobial results of the synthesized alginate, its predicted that it can be used in cosmetics as a natural material.

\section{MATERIALS AND METHODS}

\subsection{Materials and instrumentation}

Sodium carbonate $\left(\mathrm{Na}_{2} \mathrm{CO}_{3}\right)$ and calcium chloride $\left(\mathrm{CaCl}_{2}\right)$ were taken from Merck. Pseudomonas aeruginosa (ATCC 9027), Staphylococcus aureus (ATCC 6538), Candida albicans (ATCC 10231), Escherichia coli (ATCC 8739), Aspergillus brasiliensis (ATCC 16404) were purchased from American Type Culture Collection (ATCC)Incubator; ( Memmert - UN55) Centrifugal (Hettich Marka-Universal 32R).

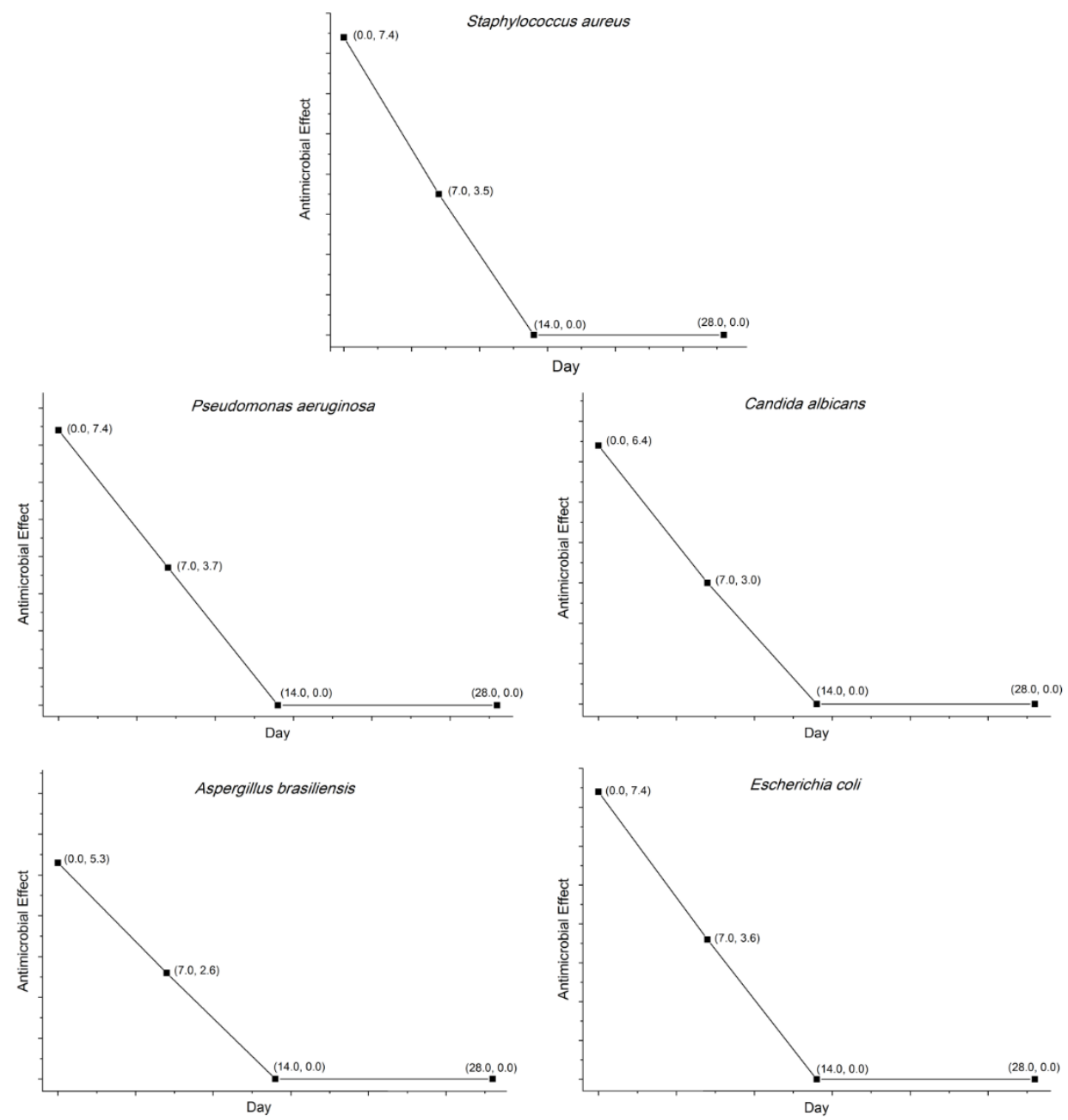

Figure 4. Antimicrobial effect of alginate extracted from Sargassum vulgare on Staphylococcus aureus, Pseudomonas aeruginosa, Candida albicans, Aspergillus brasiliensis, Escherichia coli.

Antimicrobial effectiveness test was carried out according to the ISO 11930 standard. A total of 5 organisms are used. Before the start of the test, the incoming sample was taken into microbiological analysis with a minimum of 2 parameters. As the result of this analysis was found suitable, the efficiency test was started. After the samples were exposed to artificial contamination with 5 organisms $(107-8 \mathrm{CFU} / \mathrm{ml})$, sowing was performed on days $0,7,14$ and 28. Logarithmic decreases were calculated and it was determined whether it was criterion 1 or criterion 2 according to the table below. Effectiveness is mentioned if it kills the protective organisms. Evaluation criteria are given in Table 2. 
Table 2. Antimicrobial efficacy evaluation criteria.

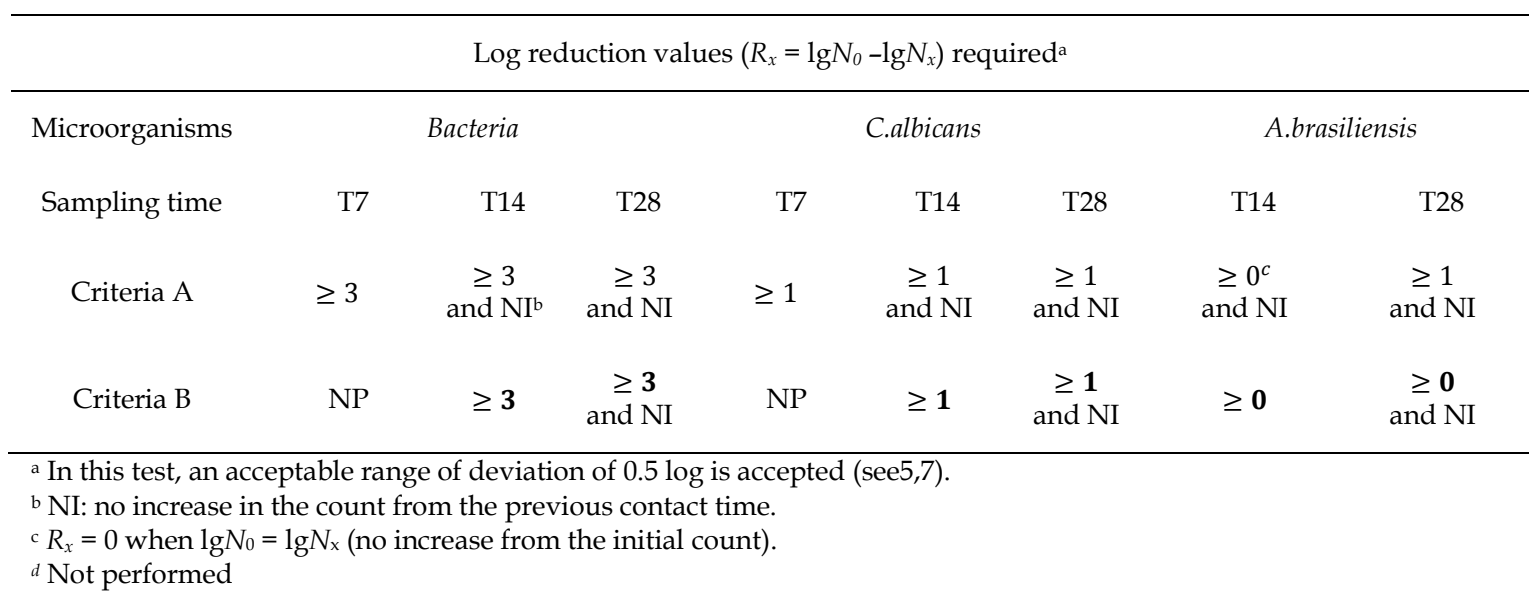

Fourier Transform Infrared Spectroscopy (FT-IR) spectrometer (Perkin Elmer, Spectrum two) was used to describe the characterization of the algae in the range of $400-4000 \mathrm{~cm}^{-1}$. To define the changing crystal structures of samples was used in a powder X-ray diffractometer (XRD, Rigaku Miniflex 600) with Cu Ka radiation and range of $10-80^{\circ}$. The surface characteristics of materials were determined by Scanning Electron Microscope (SEM) (LEO Evo-40 VPX).

\subsection{Collecting of algae}

Sampling studies, 0-20 m depth from the free dives were made in Iskenderun Bay, Hatay, Turkey, in September 2018. Sargassum vulgare were collected underwater in gathered mesh bags. Some of the materials collected were determined in jars in a 4-6\% neutralized formaldehyde solution prepared with seawater, to be determined and definitions later in the laboratory. The collected materials were separated and washed with distilled water in order to be free of epiphytes, rocks, sand and mud that may be present in them. The cleaned materials were dried in a laboratory in a shaded area without further exposure to the sun for further analysis. The identification studies of the materials were carried out with the Olympus brand Ckx41sf model stereo inverted light microscope.

\subsection{Ethanol extraction of $S$. vulgare}

Extraction was carried out according to the method proposed by Main and Percival [47]. $30 \mathrm{~g}$ of algae powder has been suspended in $300 \mathrm{ml}$ of $85 \%$ ethanol and the suspension was stirred at $450 \mathrm{rpm}$ in room temperature for $24 \mathrm{~h}$ to eliminate pigments and proteins. The suspension has been filtered through filter paper (Whatman \#4) to remove ethanol. After ethanol extraction, residual algae have been treated with formaldehyde for one night to eliminate phenolic constituents. Formaldehyde was removed by filtering. Residual algae were washed three times with distilled water.

\subsection{Alginate extraction from S. vulgare}

Alginate was extracted with sequential extraction. In the first step, washed residual algae were taken in $300 \mathrm{ml}$ of $2 \% \mathrm{CaCl}_{2}$ heated to $70{ }^{\circ} \mathrm{C}$ and shaken in the $70{ }^{\circ} \mathrm{C}$ water bath for $3 \mathrm{~h}$ at $200 \mathrm{rpm}$. Then, the solution was centrifuged at $16000 \mathrm{rpm}$ for $10 \mathrm{~min}$. Supernatant including laminarin and fucans, was removed from pellet. In the second step, the pellet was suspended with $300 \mathrm{ml}$ of $\mathrm{HCl}(0.01 \mathrm{M}, \mathrm{pH}=2)$ heated to $70{ }^{\circ} \mathrm{C}$ and shaken in the $70^{\circ} \mathrm{C}$ water bath for $3 \mathrm{~h}$ at $200 \mathrm{rpm}$. The solution was centrifuged at $16000 \mathrm{rpm}$ for $10 \mathrm{~min}$. Supernatant including fucans, was removed from the pellet. In the last step, the pellet was suspended with $300 \mathrm{ml}$ of $3 \% \mathrm{Na}_{2} \mathrm{CO}_{3}$ heated to $70{ }^{\circ} \mathrm{C}$ and shaken in the $70{ }^{\circ} \mathrm{C}$ water bath for $3 \mathrm{~h}$ at $200 \mathrm{rpm}$. The solution was centrifuged at $16000 \mathrm{rpm}$ for $10 \mathrm{~min}$. Supernatant including alginate was transferred clean falcon tubes. After extraction, alginate solution has been dialyzed in distilled water at $4{ }^{\circ} \mathrm{C}$ for $24 \mathrm{~h}$ (Figure 5). Then, the alginate powder was obtained by lyophilization. 


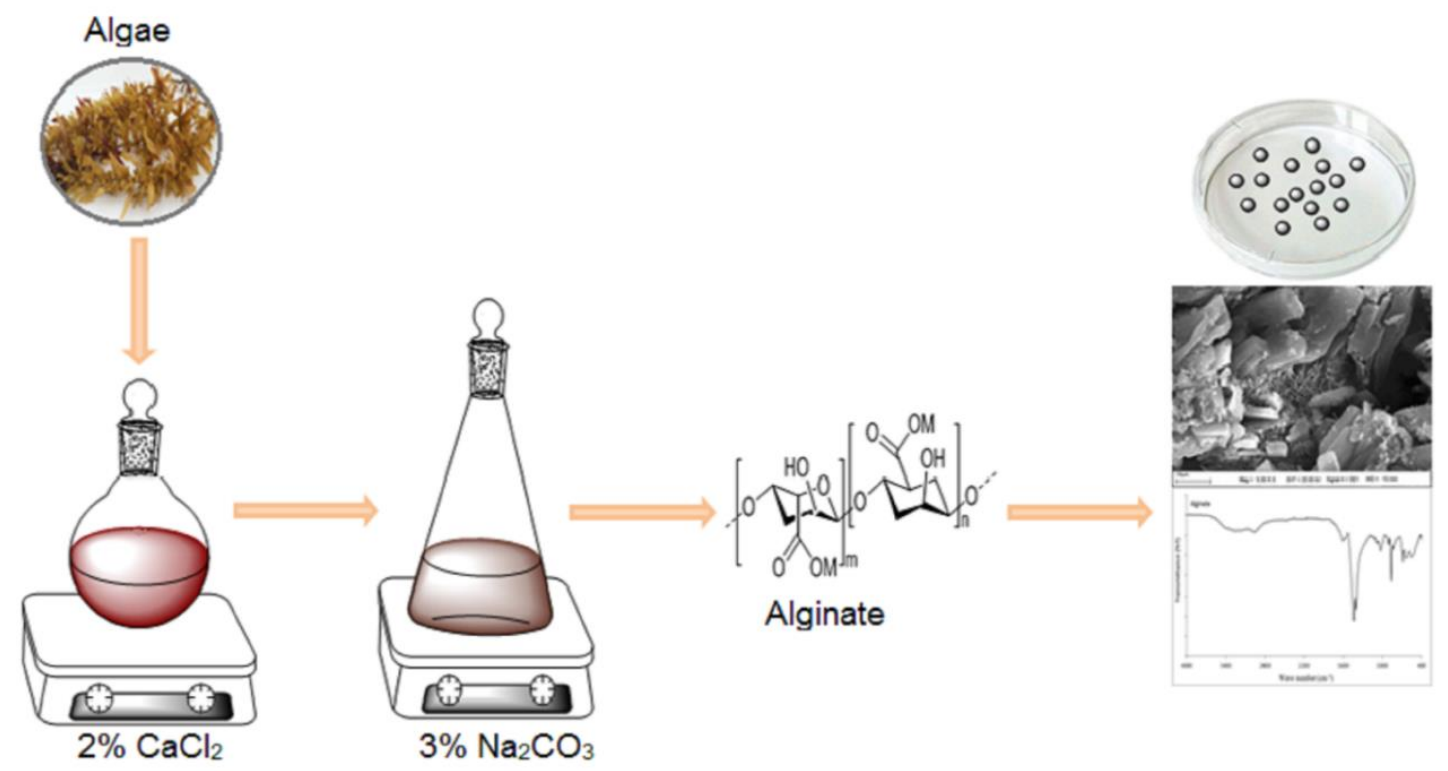

Figure 5. Schematic representation of alginate synthesis from Sargassum spp.

\subsection{Antimicrobial activity test}

The antimicrobial preservative efficacy (challenge/screening/forcing) test is based on the evaluation of microbial contamination risk by exposing the test product to artificial contamination. In this context, the antimicrobial protective activity of alginate obtained from Sargassum vulgare species was evaluated using Pseudomonas aeruginosa (ATCC 9027), Staphylococcus aureus (ATCC 6538), Candida albicans (ATCC 10231), Escherichia coli (ATCC 8739), Aspergillus brasiliensis (ATCC 16404) microorganisms. For this purpose, the protective efficacy of the alginate test product was determined by determining the number of microorganisms that survived the incubation periods (7, 14, 28 days). The parameters applied within the scope of the antimicrobial protective efficacy test, the media suitable for the microorganism, the incubation temperatures in the culturing step and the antimicrobial test method applied are shown in Table 3.

Table 3. Antimicrobial activity test of alginates extracted from Sargassum vulgare.

\begin{tabular}{llll}
\hline Microorganisms & Method & Media & Incubation Temp. \\
\hline Staphylococcus aureus (ATCC 6538) & Plate & Tryptic Soy Agar & $30^{\circ} \mathrm{C}-35^{\circ} \mathrm{C}$ \\
Pseudomonas aeruginosa (ATCC 9027) & Plate & Tryptic Soy Agar & $30^{\circ} \mathrm{C}-35^{\circ} \mathrm{C}$ \\
Candida albicans (ATCC 10231) & Plate & Tryptic Soy Agar & $30^{\circ} \mathrm{C}-35^{\circ} \mathrm{C}$ \\
Aspergillus brasiliensis (ATCC 16404) & Plate & Potato Dextrose Agar & $20^{\circ} \mathrm{C}-25^{\circ} \mathrm{C}$ \\
Escherichia coli (ATCC 8739) & Plate & Pabouraud 4\% Dextrose Agar & $20^{\circ} \mathrm{C}-25^{\circ} \mathrm{C}$ \\
\hline
\end{tabular}

Acknowledgements: Not declared

Author contributions: Concept - S.S., I.S., B.A., M.G.K.; Design - S.S., I.S., B.A., M.G.K., S.S.; Supervision - S.S., M.G.K., I.S., B.A., Z.C .; Resources - S.S., M.G.K., S.U., S.Z .; Materials -S.S., M.N., A.A., S.U .; Data Collection and / or Processing - S.S., B.A., M.G.K., S.Z.; Analysis and / or Interpretation - S.S., B.A., M.G.K., S.Z.; Literature Search - S.S., S.S., S.U.; Writing Manuscript - S.S., B.A., S.S., M.G.K., Z.C., S.Z.; Critical Reviews - S.S., M.G.K., M.N., S.S., A.A., S.U., Z.C.,I.S., B.A., T.D.

Conflict of interest statement: The authors declared no conflict of interest.

\section{REFERENCES}

[1] Uzuka A, Kobayashi Y, Onuma R, Hirooka S, Kanesaki Y, Yoshikawa H, Fujiwara T, Miyagishima S. Responses of unicellular predators to cope with the phototoxicity of photosynthetic prey. Nat Commun. 2019; 10: 5606.

[CrossRef]

[2] Perumal B, Chitra R, Maruthupandian A, Viji M. Nutritional assessment and bioactive potential of Sargassum polycystum C. Agardh (Brown Seaweed). Indian J Mar Sci. 2019; 48(4): 492-498. 
[3] Smith AJ. Medical and pharmaceutical uses of seaweed nature products; A review. J Appl Phycol. 2004; 16: $245-262$. [CrossRef]

[4] Sabaani NJ, Peñaredondo MAE, Sepe MC. Antibacterial activity of liquid soap with combined Sargassum sp. and Eucheuma sp. seaweed extracts. AACL Bioflux. 2019; 12(5): 1514-1523.

[5] Saeed AM, Abotaleb SI, Alam NG, ELMehalawy AA, Gheda SF. In vitro Assessment of Antimicrobial, Antioxidant and Anticancer Activities of some Marine Macroalgae. Egypt J Bot. 2020; 60(1): 81-96. [CrossRef]

[6] Hemraj UN, Gupta A, Jindal A, Jalhan S. Pharmacological activities of Stephania glabra, Woodfordia fruticosa and Cissempelos pareira-A review. Int J Pharm Sci. 2012; 4(3): 16-23.

[7] Cheung RCF, Wong JH, Pan WL, Chan YS, Yin CM, Dan, XL, Wang HX, Fang EF, Lam SK, Ngai PHK, Xia LX. Antifungal and antiviral products of marine organisms. Appl Microbiol Biotechnol. 2014; 98(8): 3475-3494. [CrossRef]

[8] Oumaskour K, Boujaber N, Etahiri S, Assobhei O. Screening of antibacterial and antifungal activities in green and brown algae from the coast of Sidi Bouzid (El Jadida, Morocco). Afr J Biotechnol. 2012; 8(7): 16831-16837.

[9] Osman MEH, Abushady AM, Elshobary ME. In vitro screening of antimicrobial activity of extracts of some macroalgae collected from Abu-Qir Bay Alexandria, Egypt. Afr J Biotechnol. 2010; 9(12): 7203-7208.

[10] Yoon SY, Lee SY, Kim KBWR, Song EJ, Lee SJ, Lee CJ, Park NB, Jung JY, Kwak JH, Nam KW. Antimicrobial activity of the Sargassum fulvellum ethanol extract and the effect of temperature and $\mathrm{pH}$ on their activity. Korean J Food Sci Technol. 2010; 42(2): 155-159.

[11] Yende SR, Harle UN, Chaugule BB. Therapeutic potential and health benefits of Sargassum species. Pharmacogn Rev. 2014; 8(15): 1-7. [CrossRef]

[12] Marinho-Soriano E, Fonseca PC, Carneiro MAA, Moreira WSC. Seasonal variation in the chemical composition of two tropical seaweeds. Bioresour Technol. (2006); 97: 2402-2406. [CrossRef ]

[13] Budhiyanti SA, Raharjo S, Marseno DW, Lelana IYB. Antioxidant activity of brown algae Sargassum species extract from the coastline of Java Island. Am J Agric Biol Sci. 2012; 7(3): 337-346. [CrossRef]

[14] Kim SH, Choi DS, Athukorala Y, Jeon YJ, Senevirathne M. Rha C.K. Antioxidant activity of sulfated polysaccharides isolated from Sargassum fulvellum. J Food Sci Nutr. 2007; 12: 65-73.

[15] Seo Y, Park KE, Kim YA, Lee HJ, Yoo JS, Ahn JW, Lee BJ. Isolation of Tetraprenyltoluquinols from the Brown Algae Sargassum thunbergii. Chem Pharm Bull. 2006; 54(12): 1730-1733. [CrossRef]

[16] Ryu G, Par, SH, Kim ES, Choi BW, Ryu SY, Lee BH. Cholinesterase inhibitory activity of two farnesylacetone derivatives from the brown algae Sargassum sagamianum. Arch Pharm Res. 2003; 26: 796-799. [CrossRef]

[17] Ina A, Hayashi KI, Nozaki H, Kamei, Y. Pheophytin a, a low molecular weight compound found in the marine brown alga Sargassum fulvellum, promotes the differentiation of PC12 cells. Int J Devl Neuroscience. 2007; 25: 63-68. [CrossRef]

[18] Gamal-Eldeen AM, Ahmed EF, Abo-Zeid MA. In vitro cancer chemopreventive properties of polysaccharide extract from the brown alga, Sargassum latifolium. Food Chem Toxicol. 2009; 4(6): 1378-1384. [CrossRef]

[19] Iwashima M, Mori J, Ting X, Matsunaga T, Hayashi K, Shinoda D, Satio H, Sankawa U, Hayashi T. Antioxidant and Antiviral Activities of Plastoquinones from the Brown Alga Sargassum micracanthum, and a New Chromene Derivative Converted from the Plastoquinones. Bio Pharm Bull. 2005; 28(2): 374-377. [CrossRef]

[20] Joob B, Wiwanitkti V. Sargassum species and usefulness in endocrinology. J Coastal Life Med. 2016; 4(2): 167-168.

[21] Smidsrod O, Skjakbrk G. Alginate as immobilization matrix for cells. Trend Biotech. 1990; 8: 71-78. [CrossRef]

[22] Clark DE, Green HC. Alginic acid and process of making same. 1936; US Patent. 2036922.

[23] Gedik G, Alaca S. Evaluation of the effect of anti-pollution \& anti-aging eye cream on the collagen contraction. J Pharm Technol. 2020; 1(1): 13-17. [CrossRef]

[24] Monice MF, Bart H, Wilma FB, Donald V, Ronald AH, Curtis DKl, Daniel CL, James GMJr, Ronald CS, Thomas JS, Paul WS, Alan FA. Safety assessment of polysaccharide gums as used in cosmetics. Int J toxicol. 2006; 35(1_suppl): 5S-49S. [CrossRef]

[25] Draget KI, Smidsrød O, Skjak-Bræk G. In Polysaccharides and Polyamides in the Food Industry. Properties, Production and Patents; Vandamme, E. J., De Baets, S., Steinbüchel, A., Eds.; Wiley-VCH Verlag GmbH \& Co. KGaA: Weinheim, Germany, 2005. 
[26] Sood, A.; Granick, M.S.; Tomaselli, N.L. Wound dressings and comparative effectiveness data. Adv Wound Care. 2014; 3: 511-529. [CrossRef]

[27] Draget KI. 29. Alginates. In: Phillips GO, Williams PA, eds. Handbook of Hy-drocolloids (Second Edition). Woodhead Publishing Series in Food Science, Technology and Nutrition. Woodhead Publishing. 2009: 807-828.

[28] Eiselt P, Yeh J, Latvala RK, Shea LD, Mooney D J. Porous carriers for biomedical applications based on alginate hydrogels. Biomaterials. 2000; 21(19): 1921-1927. [CrossRef]

[29] Alsberg E, Anderson KW, Albeiruti A, Franceschi RT, Mooney DJ. Cell-interactive Alginate Hydrogels for Bone Tissue Engineering. J Dent Res. 2001; 80(11): 2025-2029.

[30] Larsen B, Haug A, Painte TJ (L.), Jol L. Sulphated polysaccharides in brown algae. Isolation and preliminary characterisation of three sulphated polysaccharides from Ascophyllum nodosum. Acta Chem. Scand. 1966; 20: 219-230. [CrossRef]

[31] Haug A, Larsen B, Smidsrød O. A study of the constitution of alginic acid by partial hydrolysis. Acta Chem. Scand. 1966; 20; 183-190. [CrossRef]

[32] Halla N, Fernandes I, Heleno S, Costa P, Boucherit-Otmani Z, Boucherit K, Rodrigues AE, Ferreira ICFR, Barreiro M. Cosmetics Preservation: A Review on Present Strategies. Molecules. 2018; 23(7): 1571. [CrossRef]

[33] Bilal M, Iqbal HMN. An insight into toxicity and human-health-related adverse consequences of cosmeceuticals A Review. Sci Total Environ. 2019; 670: 555-568. [CrossRef]

[34] Herman A. Antimicrobial Ingredients as Preservative Booster and Components of Self-Preserving Cosmetic Products. Curr Microbiol. 2019; 76: 744-754. [CrossRef]

[35] Thiyagarasaiyar K, Goh BH, Jeon YJ, Yow YY. Algae Metabolites in Cosmeceutical: An Overview of Current Applications and Challenges. Mar Drugs. 2020; 18(6): 323. [CrossRef]

[36] Arguelles, EDLR. Sapin, AB. Bioactive properties of Sargassum siliquosum J. Agardh (Fucales, Ochrophyta) and its potential as source of skin-lightening active ingredient for cosmetic application. J Appl Pharm Sci. 2020; 10.7: 51-58.

[37] Wu L, Chen C, Cheng C, Dai H, Ai Y, Lin C, Chung Y. Evaluation of tyrosinase inhibitory, antioxidant, antimicrobial, and antiaging activities of Magnolia officinalis extracts after Aspergillus niger fermentation. BioMed Res Int. 2018: 11; 5201786. [CrossRef]

[38] Dolorosa MT, Nurjana, Purwaningsih S, Anwar E, Hidayat T. Tyrosinase inhibitory activity of Sargassum plagyophyllum and Eucheuma cottonii methanol extracts. IOP Conf Series: Earth Environ Sci. 2019; 278: 2-8.

[39] Jiménez JT, O'Connell S, Lyons H, Bradley B, Hall M. Antioxidant, antimicrobial, and tyrosinase inhibition activities of acetone extract of Ascophyllum nodosum. Chem Pap. 2010; 64: 434-442. [CrossRef]

[40] Bharatham BH, Abu Bakar MZ, Perimal EK, Yusof LM, Hamid M. Development and Characterization of Novel Porous 3D Alginate-Cockle Shell Powder Nanobiocomposite Bone Scaffold. BioMed Res Int. 2014; 146723: 1-11. [CrossRef]

[41] Taratra AF, Ghina A, Cedric D, Celine L, Emmanuel P, Anne W, Philippe M, Extraction and characterization of an alginate from the brown seaweed Sargassum turbinarioides Grunow. J Appl Phycol. 2010; 22: 131-137. [CrossRef]

[42] Kumar A, Buia MC, Palumbo A, Mohany M, Wadaan MAM, Hozzein WN. Ocean acidification affects biological activities of seaweeds: A case study of Sargassum vulgare from Ischia volcanic $\mathrm{CO}_{2}$ vents. Environ Pollut. 2020; 259:113765. [CrossRef]

[43] Arguelles EDLR, Monsalud RG, Sapin AB. Chemical composition and in vitro antioxidant and antibacterial activities of Sargassum vulgare C. Agardh from Lobo, Batangas, Philippines. J ISSAAS. 2019;25(1):112-122.

[44] Kolanjinathan K, Ganesh P, Govindarajan M. Antibacterial activity of ethanol extracts of seaweeds against fish bacterial pathogens. Eur Rev Med Pharmaco Sci. 2009; 13(3): 173-177.

[45] Gerasimenko NI, Chaykina EL, Busarova NG, Anisimov MM. Antimicrobic and hemolytic activity of low-molecular metabolites of brown seaweed Laminaria cichorioides (Miyabe). Appl Biochem Microbiol. 2010; 46(4): 426-430. [CrossRef]

[46] Seenivasan R, Indu H, Archana IG, Geetha S. The antibacterial activity of some marine algae from South East coast of India. Am Eurasian J Agric Environ Sci. 2010; 9(5): 480-489.

[47] Mian AJ, Percival E. Carbohydrates of the brown seaweeds Himanthalia lorea, Bifurcaria bifurcata, and Padina pavonia. Carbohyd Res. 1973; 26(1): 133-146. [CrossRef] 
[48] Pereira, Leonel; Cotas, João. Introductory Chapter: Alginates-A General Overview. Alginates-Recent Uses of This Nat Polym. 2020; 6; 97-102.

[49] Nguyen H, Munnier E, Souce M, Perse X, David S, Bonnier F, Vial F, Yvergnux F, Perrier T, Cohen-Jonathan S, Chourpa I. Novel alginate-based nanocarriers as a strategy to include high concentrations of hydrophobic compounds in hydrogels for topical application. Nanotechnol. 2015; 26(25): 255101.

[50] Byeon SY, Cho MK, Shim KH, Kim JH, Song GH, Shin SH. Development of a spirulina extract/alginate-imbedded PCL nanofibrous cosmetic patch. J Microbiol Biotechnol. 2017; 27(9): 1657-1663. [CrossRef]

[51] Shalaka D, Naik SR, Amruta A, Parimal K. Vitamin E loaded pectin alginate microspheres for cosmetic application. J Pharmacy Res. 2009; 2(6): 1098-1102.

This is an open access article which is publicly available on our journal's website under Institutional Repository at http://dspace.marmara.edu.tr. 